\title{
Performance characteristics and carcass quality of broiler chicks under high stocking density fed vitamin E supplemented diet
}

\author{
${ }^{{ }^{*}}$ Adebiyi, O.A., ${ }^{2}$ Adu, O.A. and ${ }^{1}$ Olumide, M. D. \\ ${ }^{1}$ Department of Animal Science, University of Ibadan, Nigeria \\ ${ }^{2}$ Department of Animal Science, Federal University of Technology, Akure, Nigeria.
}

ABSTRACT

Two hundred and seventy, day-old Arbor Acre strain of broiler chicks were used for this research. The birds were randomly divided into five treatment groups of $10 \mathrm{birds} / \mathrm{m}^{2} /$ replicate $\left(0.1 \mathrm{~m}^{2} / \mathrm{bird}\right)$ in Treatment 1 (positive control) while those in Treatments 2 (negative control), 3, 4 and 5 had 20 birds $/ \mathrm{m}^{2} /$ replicate $\left(0.05 \mathrm{~m}^{2} / \mathrm{bird}\right)$. Birds fed dietary Treatment 1 and 2 had no supplementation with vitamin E, whereas birds on dietary Treatments 3,4 and 5 had $50 \mathrm{mg} / \mathrm{kg}, 100 \mathrm{mg} / \mathrm{kg}$ and 150 $\mathrm{mg} / \mathrm{kg}$ vitamin $\mathrm{E}$ supplementation respectively. All treatments were replicated three times. At the end of the 4 weeks of experiment, carcass characteristics (Cold shortening (CS), Thermal shortening (TS), Cooking loss (CL), Shear force (SF) and Water Holding Capacity (WHC)) of the birds were determined. There were no significant changes in the weight gain and final weight of the birds fed the different dietary treatments. However, the feed conversion ratio (FCR) revealed that birds on dietary treatment 2 had the highest significant value of 3.29 compared to those on Vit E supplemented diets. No significant different was observed in the $\mathrm{WCH}$ of both raw $(58.43 \%$ to $59.43 \%)$ and the cooked meat $(59.02 \%$ to $59.51 \%)$ for all the treatments. Birds fed dietary treatment 2 (negative control) had the highest significant $(p<0.05)$ CS value of $3.50 \%$ compared to its counterparts on Vit $E$ supplemented diets with values ranging from $2.45 \%$ to $2.55 \%$. No significant difference was observed in the SF of the birds in all the treatment with mean value ranging from $3.35 \%$ to $3.60 \%$. In conclusion broiler chicks could be stocked up to $20 \mathrm{birds} / \mathrm{m}^{2}$ only if the diet is supplemented with $100 \mathrm{mg} / \mathrm{kg}$ Vit. E.

Keywords: Stock density, vitamin E, carcass quality, broilers

\section{INTRODUCTION}

Stress in broiler production is not only restricted to heat (high ambient temperature), but also physiological stress (as a result of increasing stocking density), nutritional stress (imbalance in the nutrient requirement) and vaccination stress etc. Increasing stocking density of broilers is a management practice used for reducing cost associated with labour, housing and equipments. However, over-crowding of broilers can lead to reductions in performance (Shanawany, 1988). Broiler performance and health can be influenced by very high stocking density (Webster, 1990) thereby it is important to ensure that adequate floor space is available for each bird (Al-Homidan, 2001). If the stocking density is too high, the temperature may rise dangerously since there will be more metabolic heat being added to the house air than was planned for.

Poultry farmers often increase stock density with the aim of increasing profit but this always result in the build up of heat and consequently leading to heat stress. Several methods are available to alleviate the effect of high environmental temperature and increased stocking density on performance of poultry. Since it is expensive to cool animal buildings, such methods are focused mostly on the dietary manipulation. In this respect, vitamin $E$ is used in the poultry diet because of the reported benefits of vitamin $E$ supplementation to laying hens during heat stress (Whitehead et al., 1998; Bollengier-Lee et al., 1998, 1999; Sahin et al., 2001), also because of the fact that vitamin $E$ levels is reduced during heat stress (Feenster, 1985; Whitehead et al., 1998; Boliengier-Lee et al., 1999; Sahin et al., 2001, 2002) . Vitamin $E$ has been recognized as an essential nutrient for growth and health of all species of animals (McDowell, 1989). The diverse roles of vitamin $E$ are due to its involvement in nutritional myopathy, prostaglandin biosynthesis and immune responsiveness (Lin et al., 1996). Asghar et al. (1991) recorded improvements in animal performance when pigs were supplemented with 100 $\mathrm{mg}$ vitamin $\mathrm{E} / \mathrm{kg}$ of feed. One of the most important 
properties of vitamin $E$ is its antioxidant function. When animals fed diets rich in unsaturated fatty acids which are susceptible to peroxidation the vitamin $\mathrm{E}$ deficiency is augmented (McDowell, 1989). Supplementation of animal diets with tocopherols increases the content of this natural antioxidant in animal food products and prevents lipid peroxidation in broiler meat (Ajuyah et al., 1993). Vitamin $E$ is known to be a lipid component of biological membranes and is considered a major chainbreaking antioxidant (Halli-well and Gutteridge, 1989). Vitamin $E$ is mainly found in the hydrocarbon part of membrane lipid bilayer towards the membrane interface and in close proximity to oxidase enzymes which initiate the production of free radicals (Putnam and Comben, 1987; McDowell, 1989; Packer, 1991). Vitamin $\mathrm{E}$, therefore, protects cells and tissues from oxidative damage induced by free radicals (GalloTorres, 1980). Sahin and Kucuk, (2001) observed that supplemental vitamin E significantly alleviated the heat stress-related decrease in performance suggesting additional vitamin $E$ supplementation into diets may be necessary under heat stress conditions in Japanese quails. Supplementing vitamin $E$ to broilers is also important to human health in terms of consuming healthier poultry meat products. Therefore, the objective of this study was to evaluate the effects of optimal dose of Vit. E supplementation on performance and carcass quality characteristics in broilers reared under increased stocking density.

\section{MATERIALS AND METHODS}

Total of Two hundred and seventy, day-old Arbor Acre strain of broiler chicks were used for this research. The study was carried out at the Teaching and Research Farm of the University of Ibadan, Ibadan for a period of four weeks. The birds were randomly divided into five treatment groups of total of 30 birds in Treatment 1 (positive control) while those in Treatments 2 (negative control), 3, 4 and 5 had 60 birds per treatment. Birds in Treatment 1 were further sub-divided into three replicates with 10 birds per replicate while their counterparts in Treatments 2 to 5 were subdivided into 20 birds per replicate. All pens were bedded with a wood-shavings litter and equipped with feeders and waterers. Birds fed dietary treatment 1 had a spacing of 10 birds $/ \mathrm{m}^{2}\left(0.1 \mathrm{~m}^{2} / \mathrm{bird}\right)$ without Vit. E (d1- $\alpha$-tocopheryl acetate) supplementation (positive control) while those in treatment 2 had a stocking density of $20 \mathrm{birds} / \mathrm{m}^{2}$ without Vit. $\mathrm{E}$ (negative control). However, birds on dietary treatments 3 to 5 had a stocking density of 20 birds $/ \mathrm{m}^{2}\left(0.05 \mathrm{~m}^{2} / \mathrm{bird}\right)$ supplemented with $50 \mathrm{mg} / \mathrm{kg}$, $100 \mathrm{mg} / \mathrm{kg}$ and $150 \mathrm{mg} / \mathrm{kg}$ respectively.

Performance data (feed intake, weight gain and feed conversion ratio) were taken weekly. At the end of day 28, 9 birds randomly chosen from each treatment (3 birds per each replicate) were slaughtered for carcass quality evaluation.

The design of the experiment was completely randomized design (CRD). Data taken were subjected to statistical analysis of variance (ANOVA) procedure of SAS, 1999. The basal composition of the experimental diets are shown Table 1.

\section{RESULTS AND DISCUSSION}

There were no significant changes in the weight gain and final weight of birds fed the different dietary treatments (Table 2). The feed intake increased significantly in birds fed T2 $(1.91 \mathrm{~kg})$ (negative control) compared to their counterpart on Vit. $E$ supplementation (1.58 to $1.60 \mathrm{~kg}$ ). However, FCR of birds fed diets T1 (2.50), T4 (2.77) and T5 (2.50) were not significantly $(p<0.05)$ different. Table 3 shows the effect of the Vit $E$ supplementation on the meat quality of broiler. No significant different was observed in the $\mathrm{WCH}$ of both raw $(58.43 \%$ to $59.43 \%)$ and the cooked meat (59.02\% to $59.51 \%$ ). Birds fed dietary treatment 2 (negative control) had the highest significant $(p>0.05)$ CS value of $3.50 \%$ compared to those on Vit $\mathrm{E}$ supplemented diets $(2.45 \%$ to $2.55 \%)$. No significant $(p<0.05)$ difference was observed in the SF of the birds in all the treatment with mean value ranging from $3.35 \%$ to $3.60 \%$. 
Table 1: Gross composition of Experimental Diet (Percentage Dry Matter Basis)

\begin{tabular}{|c|c|c|c|c|c|}
\hline $\begin{array}{l}\text { Ingredients } \\
(\mathrm{kg})\end{array}$ & $\begin{array}{l}\text { TI } \\
\text { (Positive } \\
\text { control) }\end{array}$ & $\begin{array}{l}\text { T2 } \\
\text { (negative } \\
\text { control) }\end{array}$ & $\begin{array}{l}\text { T3 } \\
\text { (50mg/kg } \\
\text { Vit. E) }\end{array}$ & $\begin{array}{l}\text { T4 } \\
(100 \mathrm{mg} / \mathrm{kg} \\
\text { Vit. E) }\end{array}$ & $\begin{array}{l}\text { T5 } \\
(150 \mathrm{mg} / \mathrm{kg} \text { Vit. E) }\end{array}$ \\
\hline Maize & 58.00 & 58.00 & 58.00 & 58.00 & 58.00 \\
\hline Groundnut Cake & 21.00 & 21.00 & 21.00 & 21.00 & 21.00 \\
\hline Palm kernel cake & 1.00 & 1.00 & 1.00 & 1.00 & 1.00 \\
\hline Fish meal & 2.00 & 2.00 & 2.00 & 2.00 & 2.00 \\
\hline Soyabean meal & 14.60 & 14.60 & 14.60 & 14.60 & 14.60 \\
\hline Bone meal & 2.40 & 2.40 & 2.40 & 2.40 & 2.40 \\
\hline Premix (Broiler starter) & 0.30 & 0.30 & 0.30 & 0.30 & 0.30 \\
\hline Salt & 0.30 & 0.30 & 0.30 & 0.30 & 0.30 \\
\hline Lysine & 0.30 & 0.30 & 0.30 & 0.30 & 0.30 \\
\hline Methionine & 0.20 & 0.20 & 0.20 & 0.20 & 0.20 \\
\hline Vitamin E $(\mathrm{mg} / \mathrm{kg})$ & 0.00 & 0.00 & 50.00 & 100.00 & 150.00 \\
\hline Total & 100.00 & 100.00 & 100.00 & 100.00 & 100.00 \\
\hline \multicolumn{6}{|l|}{ Calculated Nutrient } \\
\hline Crude Protein (\%) & 23.00 & 23.00 & 23.00 & 23.00 & 23.00 \\
\hline $\begin{array}{l}\text { Metabolisable Energy } \\
\text { (kcal/kg ME) }\end{array}$ & $3,019.27$ & $3,019.27$ & $3,019.27$ & $3,019.27$ & $3,019.27$ \\
\hline Crude fibre (\%) & 3.30 & 3.30 & 3.30 & 3.30 & 3.30 \\
\hline Calcium (\%) & 1.05 & 1.05 & 1.05 & 1.05 & 1.05 \\
\hline
\end{tabular}

Table 2: Effect of stocking density and different levels of vitamin supplementation on performance characteristics of broiler chicks.

\begin{tabular}{|c|c|c|c|c|c|c|}
\hline \multicolumn{7}{|c|}{ DIETARY TREATMENTS } \\
\hline Parameter (kg) & $\begin{array}{c}\text { TI } \\
\text { (Positive } \\
\text { control) }\end{array}$ & $\begin{array}{c}\text { T2 } \\
\text { (negative } \\
\text { control) }\end{array}$ & $\begin{array}{c}\text { T3 } \\
(50 \mathrm{mg} / \mathrm{kg} \\
\text { Vitamin E) }\end{array}$ & $\begin{array}{c}\text { T4 } \\
(100 \mathrm{mg} / \mathrm{kg} \\
\text { Vitamin E) }\end{array}$ & $\begin{array}{c}\text { T5 } \\
(150 \mathrm{mg} / \mathrm{kg} \\
\text { Vitamin E) }\end{array}$ & SEM \\
\hline Initial weight & 0.12 & 0.10 & 0.10 & 0.11 & 0.11 & \\
\hline Final Weight & 0.75 & 0.68 & 0.68 & 0.68 & 0.78 & 0.13 \\
\hline Weight gain & 0.63 & 0.58 & 0.58 & 0.57 & 0.64 & 0.43 \\
\hline Feed intake & $1.58^{\mathrm{C}}$ & $1.91^{\mathrm{a}}$ & $1.76^{b}$ & $1.58^{\mathrm{C}}$ & $1.60^{\mathrm{C}}$ & 1.03 \\
\hline $\begin{array}{l}\text { Feed conversion } \\
\text { Ratio (FCR) }\end{array}$ & $2.50^{b}$ & $3.29^{a}$ & $3.03^{a}$ & $2.77^{b}$ & $2.50^{\mathrm{b}}$ & 1.56 \\
\hline
\end{tabular}

${ }^{a b c}$ : Means on same row with different superscripts differ significantly $(P<0.05)$

$\mathrm{T} 1=10 \mathrm{birds} / \mathrm{m}^{2} ; \mathrm{T} 2=20 \mathrm{birds} / \mathrm{m}^{2} ; \mathrm{T} 3=20 \mathrm{birds} / \mathrm{m}^{2}+50 \mathrm{mg} / \mathrm{kg}$ Vit $\mathrm{E} ; \mathrm{T} 4=20 \mathrm{birds} / \mathrm{m}^{2}+100 \mathrm{mg} / \mathrm{kg}$ Vit $\mathrm{E} ; \mathrm{T} 5=20 \mathrm{birds} / \mathrm{m}^{2}+$ $150 \mathrm{mg} / \mathrm{kg}$ Vit E 
Agric. Biol. J. N. Am., 2011, 2(8): 1160-1165

Table 3: Effect of stocking density and different levels of vitamin E supplementation on carcass quality broiler chicks.

\begin{tabular}{|c|c|c|c|c|c|c|}
\hline \multicolumn{7}{|c|}{ DIETARY TREATMENTS } \\
\hline $\begin{array}{l}\text { Parameter } \\
(\mathrm{kg})\end{array}$ & $\begin{array}{c}\mathrm{TI} \\
\text { (Positive } \\
\text { control) } \\
\end{array}$ & $\begin{array}{c}\text { T2 } \\
\text { (negative } \\
\text { control) }\end{array}$ & $\begin{array}{c}\text { T3 } \\
(50 \mathrm{mg} / \mathrm{kg} \\
\text { Vitamin E) } \\
\end{array}$ & $\begin{array}{c}\text { T4 } \\
(100 \mathrm{mg} / \mathrm{kg} \\
\text { Vitamin E) }\end{array}$ & $\begin{array}{c}\text { T5 } \\
(150 \mathrm{mg} / \mathrm{kg} \\
\text { Vitamin E) }\end{array}$ & SEM \\
\hline WCH (\%) (RM) & 59.43 & 58.43 & 59.21 & 59.14 & 59.21 & 4.32 \\
\hline $\mathrm{WCH}(\%)(\mathrm{CM})$ & 59.02 & 59.51 & 59.10 & 59.07 & 59.34 & 5.14 \\
\hline Cold Shortening (\%) & $2.55^{b}$ & $3.50^{\mathrm{a}}$ & $2.45^{b}$ & $2.50^{\mathrm{b}}$ & $2.50^{b}$ & 0.51 \\
\hline Cooking loss (\%) & $38.04^{b}$ & $40.02^{a}$ & $37.64^{b}$ & $37.56^{\mathrm{b}}$ & $37.05^{b}$ & 2.11 \\
\hline Shear Force (kg) & 3.60 & 3.50 & 3.45 & 3.30 & 3.35 & 0.21 \\
\hline Thermal Shortening (\%) & $31.50^{b}$ & $26.56^{\mathrm{c}}$ & $32.56^{b}$ & $34.21^{b}$ & $37.61^{\mathrm{a}}$ & 1.54 \\
\hline
\end{tabular}

${ }^{\text {abc: }}$ : Means on same row with different superscripts differ significantly $(\mathrm{P}<0.05)$

$\mathrm{T} 1=10 \mathrm{birds} / \mathrm{m}^{2} ; \mathrm{T} 2=20 \mathrm{birds} / \mathrm{m}^{2} ; \mathrm{T} 3=20 \mathrm{birds} / \mathrm{m}^{2}+50 \mathrm{mg} / \mathrm{kg}$ Vit E; T4=20 birds $/ \mathrm{m}^{2}+100 \mathrm{mg} / \mathrm{kg}$ Vit E; T5= $20 \mathrm{birds} / \mathrm{m}^{2}+150 \mathrm{mg} / \mathrm{kg} \mathrm{Vit} \mathrm{E;}$ $\mathrm{WCH}=$ Water Holding Capacity; RM= Raw meat; $\mathrm{CM}=$ Cooked Meat

In the present study, Vit. E supplementation at $100 \mathrm{mg} / \mathrm{kg}$ with increased stock density $\left(0.2 \mathrm{~m}^{2} / \mathrm{bird}\right)$ compared favourably with birds on the positive control $\left(0.1 \mathrm{~m}^{2} /\right.$ bird $)$ in the efficiency of feed utilisation. The increase in the FCR of birds on diet 2 (negative control) could be attributed to the increase in stress resulting from competition for feed, and water, increase of house temperature, microbial activity and ammonia production.

Kennedy et al. (1992) examined the productivity of 168 broiler flocks fed diets containing either $50 \mathrm{mg} / \mathrm{kg}$ or $180 \mathrm{mg} / \mathrm{kg}$ dietary vitamin $\mathrm{E}$. The authors reported that at the greater level of vitamin $\mathrm{E}$ supplement, productivity was $8.4 \%$ greater as a result of improvements in both FCR and higher average weight gain. Similarly, Sahin and Kucuk (2001) found that dietary vitamin $\mathrm{E}$ inclusions resulted in a greater performance in Japanese quails reared under heat stress $\left(34^{\circ} \mathrm{C}\right)$. The Vit. E supplementation was able to ameliorate the effect of heat stress that would have resulted from the overstocking. Ushakova et al., 1996 shown that dietary supplements of vitamin $\mathrm{E}$ can modify gene expression induced by heat shock in vivo and have a protective role against oxidative stress by enhancing the level of endogenous antioxidants and inducing heat shock protein (hsp)-70 gene expression. Organisms respond to elevated temperatures and physiological stresses by an increase in the synthesis of heat shock proteins (Hsp) or stress proteins. According to Sahin et al 2002, under high environmental temperature, the expression of genes for Hsp will be enhanced and the proteins will accumulate in cells. The authors further reported that vitamin $\mathrm{E}$ supplementation in heat stressed broiler house resulted in better performance, perhaps due to increased Hsp synthesis. The cells with increased Hsp exhibit tolerance against the additional stress. The low FCR in vitamin supplemented group is also in agreement with the earlier reports of Villar et al. (2002) who reported that feed efficiency increased statistically with vitamin supplementation. Contrary to the result obtained, AlHomidian (2001) revealed that there was no significant difference in broiler performance due to stocking density However, the study revealed that increased stocking density reduced feed utilisation in broiler as shown by birds fed dietary Treatment 2 $\left(0.05 \mathrm{~m}^{2} /\right.$ bird $)$.

Meat quality evaluation is important in improving meat production (Barbera and Tossone, 2006) and carcass quality is the measure of carcass palatability and acceptability to the consumer (Renand and Fisher, 1997). The cooking loss is a combination of liquid and soluble matter lost from meat during cooking. At increasing centre temperatures the water content of the meat has been shown to decrease, and the fat and protein content to increase indicating that the main part of cooking loss is water (Heymann et al., 1990). Thus water loss is of economic concern because it affect weight loss along distribution chain during cooking (Okubanjo et al., 2003). The least cooking loss was observed for birds fed diets supplemented with Vit E, this therefore shows that the antioxidation effect of the Vit $E$ resulted into the reduction in the cooking loss. This will however affect the optimal eating quality and is of great importance to the catering industry. The cooking loss depends on the raw meat quality as reported by Asalyng et al (2003), meat with high cooking loss will have lower water holding capacity $(\mathrm{WCH})$ as shown in this result. The WHC fell within the ranges of $42.22 \%$ to $66.97 \%$ values reported by Omojola and Adeshinwa, 2006 for scalded, singed and conventionally dressed rabbit carcasses. The WHC in birds fed the negative control 
diet was reduced because the birds were subjected to stress which might have increased the water loss by panting resulting into a reduction in the space within the myofibrillar protein network with a consequence decrease in water lowering the WHC. Differences in Shear force may represent changes in the elastic characteristics of the connective tissue of different muscle which had different mechanical properties as reported by Robertson et al.,(1984). The non- significant values observed in the result could be a function of age of the birds (4 weeks), the birds are still growing and the muscles are not fully developed thus the Vit E supplementation did not produced any noticeable change

\section{CONCLUSION}

The stocking density of broilers chicks could be up to $20 \mathrm{birds} / \mathrm{m}^{2}$ only if the diet is supplemented with $100 \mathrm{mg} / \mathrm{kg}$ vitamin $\mathrm{E}$.

\section{REFERENCES}

Al-Homidan, A. A (2001). The effect of temperature and stocking density on broiler performance and ammonia production. Egypt Poult. Sci., 21: 1121-1137

Aslyng, D.N., Berjerholm, C., Ertbjerg, P, Bertram C.H and Andersen H.J. (2003). Cooking loss and juiceness of pork in relation to raw meat quality and cooking procedure and food quality preference Meat Science 14: 277-288

Ajuyah A.O., Hardin R.T. and Sim J.S. 1993: Effect of dietary full-fat flax seed with and without antioxidant on the fatty acid composition of major lipid classes of chicken meats

Barbera, S. and Tassone S. (2006). Meat cooking shrinkage. Measurement of a new meat quality parameter. Meat Science. 39: 234-238.

Bollengier-Lee S., Williams P.E.V. and Whitehead C.C. (1999): Optimal dietary concentration of vitamin E for alleviating the effect of heat stress on egg production in laying hens. Brit. Poultry Sci., 40, 102-107

Feenster R. (1985): High temperatures decrease vitamin utilization. Misset Poultry, 38-41.

Gallo-Torres D.C. (1980): Absorption, blood transport and metabolism of vitamin E. In: Maclin L.J. (ed.): A Comprehensive Treatise. Marcel Dekker, New York. 170267.

Halliwell, B. and Gutteridge J.M.C. (1989). Free Radicals in Biology and Medicine. 2nd ed. Oxford University Press, New York.

Heymann H.J., Hedrick, H. B., Karrasch, M. A., Eggeman, M. K and Ellersieck, M. R. (1990). Sensory and chemical characteristics of fresh pork roasts cooked to different centre temperature. Journal of food science 55: 613-617.

Kennedy D.G., Rice D.A., Bruce D.W., Goodall E.A. and Mcllroy S.G. (1992): Economic effects of increased vitamin $E$ supplementation of broiler diets on commercial broiler production. Brit. Poultry Sci., 33, 1015-1023.

Lin, Y.L. I.M. Juan, Y.L. Chen, Y.C. Liang and J.K. Lin (1996). Composition of polyphenols in fresh tea leaves and associations of their oxygen- radical-absorbing capacity with antipoliferative actions in fibroblast cells. J. Agric. Food Chem., 272: 1433-1436

McDowell L.R. (1989): Vitamins in Animal NutritionComparative Aspects to Human Nutrition. In: Mc Dowell L.R. (ed.): Vitamin A and E. Academic Press, London. 10-52, 93-131.

Okunbanjo, O.A., Omojola, A.B., Ogunsola, O.O., Adewumi, M.K., Ajiboro, G., Alabi, G.F and Babayemi, O.J. (2003). Meat Characteristics of Bunaji, Gudali and Keteku breeds of cattle. Tropical Anim. Prod. Invest. 6: 185

Omojola, B and Adesehinwa, A.O.K (2006). Meat characteristics of scalded, signed and conventionally dressed rabbit carcasses. At international Digital Organisation Scientific information, online vol.1 No 1:CCC-CCC

Packer, L. (1991). Protective role of vitamin E in biological systems. Am. J. Clin. Nutr., 53, 1050-1055.

Putnam, M.E. and Comben, N. (1987). Vitamin E. Vet. Rec., 121, 541-545.

Renard, G and Fisher, A.V. (1997). Comparison of methods for estmation carcass fat content of young charolis bull in performance testing station. Livestock Production Science: 51: 205-213

Robertson, J., Ratcliff. D.P.E., Bouton, P.V., Harris and Shorthose, W.R. (1984). Effect of cooking temperature and age on the shear properties of beef and buffalo meat. J. Food Sci. 49: 1163-1166, 1177

Sahin K. and Kucuk O. (2001): Effects of vitamin C and vitamin $\mathrm{E}$ on performance, digestion of nutrients, and carcass characteristics of Japanese quails reared under chronic heat stress $\left(34^{\circ} \mathrm{C}\right)$. J. Anim. Physiol. Anim. Nutr., 85, 335-342.

Sahin K., Kucuk O., Sahin N. and Sari M. (2002): Effects of vitamin $C$ and vitamin $E$ on lipid peroxidation status, some serum hormone, metabolite, and mineral concentrations of Japanese quails reared under heat stress $\left(34^{\circ} \mathrm{C}\right)$. Int. J. Vitamin Nutr. Res., 71, 91-100.

Sahin K., Sahin N., Onderci M., Yaralioglu S., and Kucuk O. (2001): Protective role of supplemental vitamin E on lipid peroxidation, vitamins $\mathrm{E}, \mathrm{A}$ and some mineral 
concentrations of broilers reared under heat stress. Vet. Med. - Czech, 46, 140-144.

SAS Institute (2008): SAS User's Guide, Version 9.2: Statistics. SAS Institute Inc., Cary, NC

Shanawany, M.M. (1988). Broiler performance under high stocking densities. Br. Poult. Sci. 29: 43-52

Ushakova, T; Melkoyan, H; Nikonova, L; Mudrik, N; Gogvadze, V; Zhukova, A; Gaziev, A.I. and Bradbury R. (1996). The effect of dietary supplements on gene expression in mice tissues. Free Radic. Biol. Med., 20, 279-284
Villar PG, Diaz CA, Avila GE, Guinzberg R, Pablos JL and Pina E (2002). Effects of dietary Supplementation with vitamin $\mathrm{C}$ or vitamin $\mathrm{E}$ on growth performance in broilers. American Journal of Veterinary Research 63 (5): 573-576.

Webster, A.J. (1990). Housing on respiratory disease in farm animals. Outlook on Agriculture, 19: 31-35

Whitehead, C.C; Bollengier-Lee S; Mitchell, M.A. and Williams, P.E.V. (1998). Vitamin E can alleviate the depression in egg production in heat stressed laying hens. In: Proc. of Spring Meeting, WPSA-UK Branch, Scarborough, 55-56. 